\title{
EUROPE IS DEAD - ON THE PHILOSOPHY OF LIBERATION OF ENRIQUE DUSSEL ${ }^{2}$
}

ABSTRACT. This paper discusses the idea of the Other in the works of the leading theoretician of the philosophy of liberation, Enrique Dussel. Although the philosophy of liberation is an authentic thought that establishes its principles in contrast to the fundamental propositions of European reflexive culture, the wider audience outside Latin America is little acquainted with it. It is a philosophy that analyzes the Other in a scope of dialectics of the center and periphery, relating the civilized and developed world to the idea of the first, and the rest of the world to the latter, for which the "first" one shows a direct and concrete interest. The practical sphere is brought into connection with the ontological one: the enslaved and exploited Other is marginalized to the periphery of being; in fact, he is made into non-being. His destruction is effected: as the one who is not me (multitude), the Other is at first made second-rated and thus less valuable (hierarchy) by the mere accidence of non being European (paradigm), only to be then easily thrown into non-existance, evened with nothingness (annihilation). Such an attitude implies an uncritical philosophy of domination, a particular imperial ontology, which is articulated as a hegemonic speech of (European) being and represents the theoretical completion of practical attitude toward the downtrodden Other. (Dussel accepts the Levinasian concept of the imperial

\footnotetext{
ubuntera@mail.ru
}

2 This paper is written in scope of project „History of Serbian Philosophy“ (ID no. 179064), financed by Ministry of education, science and technology of Republic of Serbia.

This paper was submitted on 16 August 2015 and accepted for publication at meeting of the Editorial Board held on 8 October 2015. 
character of Western thought). A special place is given to the fundamental subject of Modernity, the ego cogito, which on a practical level turns into an aggressive and annihilating ego conquiro of real historical and cultural oppression, being politically profiled through Homo homini lupus, and ontologically through polemos pater. Its certainty is self-certainity of the conquistador, the winning side in war, Lord - the Other is the pueblo, people. Resolution of the conflict, however, lies in the preference of neither the center nor the periphery, but in their dialectical mediation. However, according to Dussel's opinion, this neither should nor could prevent the articulation of an authentic voice and action of the Other, who autonomously creates his history and, in the place of Nietzsche, declares: Europe is dead.

KEY WORDS: I/ The Other, center/ periphery, being/ non-being, ontology, ego cogito/ ego conquiro, Europe/ Latin America, opposition.

Dedicated to Mihailo Marković (1923-2010)

At the end of the ' 60 s of the $20^{\text {th }}$ century, in the time of the birth of postmodernism, independently and with big differences, arose the philosophy of transmodernity in Latin America. Its founder and the main represantative is Argentinean philosopher Enrique Dussel (1934- ), whose standpoint we intent to present here. He is the author of nearly sixty books (the most important ones are translated into English), about four hundred philosophical texts, ${ }^{3}$ visiting professor at eminent European and American universities, such as Johann Wolfgang Goethe in Frankfurt, Duke, Harvard, and NotreDamme (to mention just the most famous ones). He also lectured at more than seventy universities in Latin America, Africa, Asia, Europe, and the USA. Dussel lives and works in Mexico. He developed the term "transmodernity" in his oral and written philosophical conversations with philosophical authors, such as Richard Rorty, Karl Otto Apel, Emmanuel Levinas, and Jürgen Habermas, etc. It was the aim to differentiate his philosophy from postmodernism, with which (except for the period of birth and expansion) it had no common philosophical points. In fact, transmodernity is far different from postmodernism.

The heart of Dussel's philosophy of transmodernity is his philosophy of liberation, a completely authentic Latin American philosophical thought. Although its implicit roots can be traced

3 The complete bibliography of Enrique Dussel can be found on his website: http://enriquedussel.com/cv_es.html\# - web-page visited September $13^{\text {th }} 2015$. 
back to the $16^{\text {th }}$ century with the first critiques of the conquest of America (de las Casas, Montesinos) and lead throughout the $18^{\text {th }}$ and $19^{\text {th }}$ century emancipatory discourses ?n the independence from colonial forces (Bolívar, Santander), the year 1969 is considered to be the year of its birth. It was then that Dussel encircled and perfected the categorical frame for liberation philosophy. It arouse on the background of important historical and theoretical events: the Cuban Revolution (1959), the Second Vatican Council (1962-65) and the Latin American Episcopal Conference, where "the church of people" was established (1968), the theology of liberation, the Latin American populism, dependence theory in sociology, and "the liberation of universities" in 1968. (Mendieta, 1993: viii et passim)

The people of Latin America have a long history of colonial sufferings and struggles in which the Church played an important role through the theology of liberation, especially from the 1950s onward. Its founder was the Peruvian priest Gustavo Gutiérrez, who coined the term, and the representatives among the others were Leonardo Boff (Brazil), Ernesto Cardenal (Nicaragua), Juan Luis Segundo (Uruguay), Rutilio Grande and Óscar Romero (El Salvador). The official Roman Catholic Church condemned the movement for its revolutionary and Marxist views that advocated for the poor and oppressed, and for the striving for their economic, social and political justice. As a philosopher, Dussel understood that the theology of liberation needed its theoretical founding. His engagement was on the side of providing it with a conceptual framework and enabling it to become a metaphysics, within which the revolutionary struggle was to be conceptually deduced and effective.

The main subject of liberation philosophy is pueblo, the people. They are the poor, the oppressed, the week, the "colored", women, youth and elders of the former colonies; those who were and always are the despised "other" for Europeans. In the core of European modern philosophy is found the ego cogito, I think, which practically reveals itself as ego conquiro, I conquer, I enslave, and I win wars. One needs only a glance into the modern history of the colonization of the New World to convince themselves of it. (Dussel, 1996: p. 15) The Other, who is always of anther race, sex and culture, is the object of conquering as he is the object of cogitation. $\mathrm{He}$ is never regarded as the other subjectivity, but is objectified and reduced to a mere other, the means, an instrument, an object of 
observation, interpretation, experimentation, and use - a being at the disposal of the European will to power. For Europeans, the European ego is the absolute paradigm of rationality, sense and humanity. For them, there exists an equivalence among the notions of thinking being, the human being, and European nations. Consequently, as the one who is not European, the Other (African, Asian, Latin American, Slavic we would add) is automatically a savage, a barbarian. He is not an animal rationale, not a human, not a subject; he is senseless and practically nothingness. In this way, the Other is made second-rate and less valuable in European theory and reduced to non-being in praxis. ${ }^{4}$ It is important to understand that the space of traditional European philosophy is not a neutral scientific space. It is a space of conflict, opposition, capitalistic competition and war. Its theoretical definition is given in the maxim polemos pater and its practical definition in the Hobbesian Homo homini lupus. They both reach their peak and Fichtean unity in the conquering, oppressive character of ego cogito.

To understand this, one ought to consider, aside from the notion of the Other, the two other main ideas of liberation philosophy; the idea of the center and the idea of a periphery. The center is to be understood as the developed center of imperial capitalism, whose power is globally spread and supported politically, ideologically

4 Nevertheless, Dussel is not quite right when he deduces identity between the Other and non-being, at least if we talk of non-being as nihil absolutum. The latter dialectics between center and periphery should prove our argument. Although Dussel on several occasions underlines that for a center the periphery does not exist (for the European, the Other is nothing), the nature of capitalism shows the opposite. Capitalism can only survive and expand on behalf of its non-capitalistic surrounding (the periphery, the Other). This puts the periphery and the Other in the main plane of events. But, Dussel certainly is right when he speaks of a certain annihilation of the Other from the part of "the first", the European. Yet, this reduction is not a reduction to non-being, but rather to a second-rate being, a mere other, a thing, an instrument. When this reduction is effected, "all is possible, from making soap with the fat of martyred bodies to training dogs to violate women as a torture (the former was seen in Nazi Germany, the latter in Chile in 1976). The reification of the Other allows aristocracies to manage persons as plurality, multitude, rogues, animals with logos but not human beings, as Aristotle taught with regard to the slaves in Greece." (Dussel, 1985: p. 54) If we speak of non-being in this context, then it must be spoken of as nihil relativum or nihil privativum, not nihil absolutum. This opens the space for the Other to be nothing and yet, at the same time, to be something - not a human, but neither nothingness. This remark is important for ontology but not for ethics; in order for ethics to be reduced to a mere other, is to be reduced to non-being. 
and militarily. It consists of Europe (in particular Western Europe), the USA, Canada, and Japan. ${ }^{5}$ The periphery, on the other hand, consists of the so-called underdeveloped countries of the Third World, the former colonies of the center: Africa, Asia, and Latin America. The relation of the center to the periphery is that of a domination, oppression and exploitation; it is a Hegelian masterservant relationship that, nonetheless, covers every field of human existence - theory, praxis and poiesis. In the arum of theory, this relationship is manifested by imperial science and philosophy, and ontology in particular. In the field of praxis, it covers all human relations: between man and man (politics), man and woman (erotic), master and pupil (pedagogy), etc. Political oppression is expressed through the installation of bourgeois governments (today we would say: puppet regimes) that fulfill the interests of global capitalism - an aim whose accomplishment is guaranteed by a strong militia or army, terrorizing and killing the people (juntas, death squads). ${ }^{6}$ Erotic oppression is manifested through fallocracy

5 In the earlier phases of his work, Dussel considered the former Soviet Union as a part of the center. One must criticize such a definition. Firstly, the center does not include the whole of Europe, only Western Europe. (Let us remember that in the actual EU, not all state-members have an equal vote. The main decisions are made by twelve major countries (all of them Western) and the rest of the countries mainly follow and effect their will as the will of a "united Europe". Anther reminder is the status of Slavic people in Europe: in history they were and still are treated as second-rate race, although they are the domecils of the European continent; WWII resulted in millions of Slavic victims, and it is well known that Hitler's plan was for the extermination of thirty million Slavs, the "Untermenschen", in his "cleansing the Lebensraum".) Secondly, one cannot treat the USSR as the country of the center, for it has never been capitalistic and did not have imperial tendencies. When one speaks of the Prague spring, it is often forgotten that it was the Chekiang secretary of the Communist Party Antonin Novotny who directly called the USSR troops for help, and therefore one cannot speak of a Russian "invasion" of Czechoslovakia. It seems that Dussel himself did not avoid some of the effects of the American Cold War propaganda.

6 The events in Libya and the whole of the so-called „Arab spring" are just the recent examples of such a politics, as is the current situation with refugees coming mainly from Syria, running away from DAESH. In the Balkans, the most prominent example is the brutal tearing apart of Socialistic Federative Republic of Yugoslavia accompanied by war and the 1999 NATO agression, which ended with a more than a decade long experience of Serbian people with the so-called "democratic government" that ruined the country economically, polliticaly and culturally, derogating it to its core, stripping the people from their national, historical, cultural and, finally, human pride, continuing the processes of secession in Kosovo and Metohija, with new potential burning points. 
and uxorcide; through objectifying subordination of women. Pedagogical oppression is, in Dussel's opinion, its direct consequence. Filicide is socially revealed when the development of schools produce experts in the service of the system and its imperial ideology, and inspires repetitive learning and a suppression of originality. In the sphere of production, the center dominates through alienation of labor and through production and manipulation of need, desire, and mass culture with the aim of an eradication of the authentic popular cultures.

The center is totality, permeating all the pores of human life; in an ontological perspective, it covers the whole realm of being. What is beyond the system is non-Being. Being is, non-being is not; the center is, the periphery is not - politics reveals the sense of ontology. (Dussel, 1996: p. 17) In Dussel's opinion, ontology, the discourse of being, is nothing but the ideology of the center, an imperial ontology, as Levinas named it. In line with being stand: meaning, culture, civilization. In line with non-being stand nonsense and barbarism. Nevertheless, Dussel points out that European philosophy and ontology were born on the periphery and not in the center of the ancient, medieval or modern worlds. However, they gravitated toward the center, losing their critical orientation and transforming into the philosophy of domination and the theoretical hegemony of dominant classes. (Dussel, 1996: p. 15 et passim) Dussel, on the contrary, affirms a metaphysics that, due to its potential to transcend the center (go beyond, meta-), represents the ground for a new philosophy, the authentic philosophy of the periphery, the liberation philosophy.

In the center of this philosophy is the Other, el pueblo. These are the peripheral nations, and - in the scope of one nation - the oppressed classes. The totality of a peripheral nation is not pueblo, pueblo are only its oppressed classes. In Dussel's words, the people are exterior and anterior to capitalism. They have their history and identity before colonization and retain exteriority even under the colonial, imperial oppression. When included in the totality of the imperial capitalistic system, the people forms transcendence in immanence. The poor, the unemployed, and the beggars are marginalized; capitalism has no use for them, they are a "surplus" to use Lacanian terms - a plus value that cannot be integrated into the process of profit extraction. The people of the periphery have a historical and cultural exteriority to the center, because they have a way of life that is distinct from the system. (Dussel, 1996: p. 90) 
From this distinction, exteriority, and authenticity, one should look for the potentials for liberation: "When we speak of liberation, by this we understand simultaneously the liberation of peripheral nations and the taking of power by the hands of the popular classes in the aim of an effective reorganization of the social formation." (Dussel, 1996: p. 97 - author's translation) The project of liberation consists of a destruction of the old and unjust order in the aim of establishing a new and just one - socially, economically, culturally, etc. Its goal is the establishment of utopia. This is not a kind of a utopia Adorno or Marcuse spoke of. For Dussel, those were the dreams projected in the future, without anterior criticism and cleansing of the residua of traditional, hegemonic ontology. The utopia that liberation philosophers thrive for is really a non-place, a place that has never existed before and is wanted and meant, not in the future but in the present.

The struggle for liberation is not uniform; it is distinct for every nation and country, and comes from the distinctiveness of every nation:

"The pure dominion of the dominating center cannot define intrinsically every depending nation; dependency is only one aspect of the totality of a peripheral nation that does not include exteriority of the nation itself." (Dussel, 1985: p. 74)

The liberation must be at the same time both social and national. To be more precise, it must be effective in every sphere of human engagement. That is why Dussel develops the whole system of liberation. Besides philosophy and politics, we have an economic, ethic, aesthetic, erotic and pedagogy of liberation. In each of these, he calls upon a liberating capacity in authenticity, exteriority, and proximity of the Levinasian face-to-face relation, which originally defined the people's manera de vivir (way of life). He calls upon creative non-alienated labor, non-alienated relations between men, men and women and parents and children, upon the beauty of wrinkled faces of peasants whipped by wind and hard work, upon the authentic popular culture in defense of and against the surrogate mass culture produced by the system. Dussel calls for a high revolutionary morality, temperance and discipline.

Before everything else, however, the process of liberation must start with an atheistic critique of religion. The religion to be criticized is not any particular religion - it is the faith in a system. To be liberated, firstly one ought to be an atheist in the system, and 
against fetishes. Fetishization is the process whereby a totality is absolutized and divinized. To negate the divinity of the fetishized system is authentic atheism. (Dussel, 1996: p. 118, 120) When philosophers of liberation say: "God is dead!", what they mean is that Europe is dead. It is dead because it divinized itself, it identified with God. When they proclaim the death of Europe, they terminate with Europe as a fetish. In the process of antifetishization, the Divine Other (God) is not deconstructed. He is kept as a "necessary hypothesis" (Proudhon). The mere negation of the divinity of the system without the positive affirmation of something other is not dialectical Aufhebung, for it always leaves space for the future divinization of some other system. For the system to be negated and transcended, another principle must be affirmed in its positivity. The affirmation of the "absolute Exteriority" (God) means closing the path for the future negation of the liberation affirmation. (Dussel, 1996: p. 122)

This was a short attempt to present the rich thought of the most prolific Latin American 20th century philosopher. Yet, one may still ask: What is the relevance of liberation philosophy today? Since September 11th, the notion of security and not the concept of liberty or liberation has come to be in the absolute focus of theoretical interest. The problem of security can and should not be treated regardless of liberty. There cannot be effective security without liberty, neither internally nor externally. Only a liberated state, whose people live and think freely, and are aware of their liberty, is a truly secure state - to paraphrase Hegel. However, it seems that the question of liberty is put ad acta today. In fear of terrorism, people in the Western countries willingly give up their privacy. Baudrillarian analysis gives us a good insight into it; there is nothing more natural than to put one's destiny in the hands of another. The only feeling that matters is the absence of pain and the presence of physical pleasantness; hedonism has become the main attitude. Security and liberty are exchanged for surrogates of control, power, and a "happy letting go". This only shows that the problem of liberty, internally and externally viewed, is far from being solved. From a geopolitical standpoint, though slavery formally ended in the 19th and colonization in the 20th century, they have survived in the form of neoliberal capitalism and the so called democratically elected, essentially puppet regimes, that exploit their people. That is what makes liberation philosophy interesting and relevant for us today. For - to cite a revolutionary 
poet's adaptation of the Haille Sellasie's address to the United Nations in 1963 -

"Until the philosophy which holds one race superior and another inferior is finally and permanently discredited and abandoned; and until the basic human rights are equally guaranteed to all without regard to race, everywhere is war. Until that day, the dream of lasting peace, world citizenship, rule of international morality will remain but a fleeting illusion to be pursued, but never attained." (Marley, 1976: s. 9) preliminar y bibliografía de Germán Marquínez Argote. Bogotá: Nueva América. Dussel, 1985: Dussel, E. (1985). Philosophy of Liberation. New York: Orbis Books. Dussel, E. (1988). La Ética de la Liberación - Ante el Desafío de Apel, Taylor y Vattimo con Respuesta Crítica Inédita de K. O. Apel. Universitad Autóctona del Estado de México.

Dussel, E. (1993). The Underside of Modernity: Apel, Ricoeur, Rorty, Taylor, and The Philosophy of Liberation. New Jersey: Humanities Press.

Dussel, E. (1996). Filosofía de Liberación. Bogotá: Nueva America.

Mendieta, E. (1993). “Editor's Note”. In: Dussel, E: The Underside of Modernity: Apel, Ricoeur, Rorty, Taylor, and The Philosophy of Liberation (p. vii-xi). New Jersey: Humanities Press.

Marley, B. and The Wailers (1976). War. In: Rastaman Vibration. Kingston: Island. 
ВИШњА Д. КНЕЖЕВИЋ

УНИВЕРЗИТЕТ У БЕОГРАДУ

ФИЛОЗОФСКИ ФАКУЛТЕТ

ИНстиТУТ ЗА ФИлОзОФИјУ

РЕЗИМЕ

ЕВРОПА ЈЕ МРТВА - О ФИЛОЗОФИЈИ ОСЛОБОЪЕЬА ЕНРИКЕ ДУСЕЛА

Аутор разматра идеју Другог у радовима еминентног аргентинског филозофа ослобођења Енрике Дусела. Дусел анализује Другог у контексту тзв. дијалектике центра и периферије, где се центар - развијени и „цивилизовани” свет - везује за европску идеју субјективности као ego cogito-a, док се Други идентификује као пуко друго, остатак света, за који онај „први” (Европљанин) показује непосредан и конкретан интерес. Други, народ (el pueblo), предмет је поробљавања и експлоатације и као такав, маргинализован је на периферији бића. Европску онтологију и филозофију Дисел, следећи Левинаса, идентификује као мишљење доминације и империјализма, хегемонски дискурс који представља теоријско довршење једне асимилаторске и анихилаторске праксе. Разрешење овог конфликта, према Дуселу, међутим, није у давању предности центру или периферији, већ у њиховом дијалектичком посредовању. Но, то не би требало да спречи артикулацију гласа и акције Другог, који ствара своју аутономну историју и ничеовски објављује смрт Европе.

КљУчнЕ РЕчИ: コа/ Други, центар/ периферија, биће/ небиће, онтологија, ego cogito/ ego conquiro, Европа/ Латинска Америка, супротстављање. 